\begin{tabular}{|c|c|c|}
\hline $\bar{J}$ & International Journal of Current Research in & \\
\hline & Biosciences and Plant Biology & $\div 33^{\circ}$ \\
\hline $\begin{array}{l}\text { EXCELLENT } \\
\text { PUBLISHERS } \\
\end{array}$ & 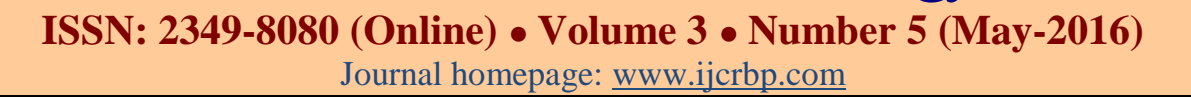 & \\
\hline
\end{tabular}

\title{
Functioning of Liquid Bio-ameliorant in Reduction of Inorganic Fertilizer to Improve Soil Quality and Maize Productivity
}

\author{
Burhanuddin Rasyid*, Masyhur Syafiuddin and Muh. Ansar \\ Department of Soil Science, Faculty of Agriculture, Hasanuddin University, Jl. Perintis Kemerdekaan, Kampus Unhas \\ Tamalanrea - Makassar 90245, Indonesia \\ *Corresponding author.
}

\begin{abstract}
A b stract
Improving soil quality and plant productivity is still challenging in sustainable agriculture. The purpose of this research was to obtain sustainable crop management in effort to improve soil quality and increase maize production through the evaluation of the functioning of liquid bio-ameliorant in reduction of chemical fertilizer utilization. Factorial experimental design with three treatment factors and three replications applied and Duncan multiple range test was used to analysis the effect of treatment on all parameters evaluated.The treatment consists of two levels of planting space and three levels of liquid bio-ameliorant and nitrogen fertilizer in each. The result shown in soil quality parameters such as microbial density was increased approximately $28 \%$ and soil chemical properties was indicated improved in combining liquid bio-ameliorant and reducing nitrogen fertilizer application. In the same line, a significant improvement of biological yield was found in plant height, number of plant leaves, biomass weight, and content of plant nutrient parameters. The highest production of $9.00 \mathrm{ton} / \mathrm{ha}$ as the result of application $300 \mathrm{ml} / \mathrm{l}$ bio-liquid ameliorant + urea $240 \mathrm{~kg} / \mathrm{ha}$. Based on the result achieved the great potential of liquid bio-ameliorant to reduce chemical fertilizer and useful to sustain crop production and improve soil quality.
\end{abstract}

\section{Article Info}

Accepted: 08 April 2016

Available Online: 06 May 2016

\section{Keywords}

Liquid bio-ameliorant

Productivity

Soil quality

Sub-optimal soil

\section{Introduction}

Maize is an important plant economically and become the second staple food in Indonesia. This figured could be shown from the total of cultivation area around $3,837,000$ ha with total production $19,008,426$ ton and production demand every year is still increase (BPS, 2014). In fact low productivity is the main problem of maize production which is the most challenge to fulfill national maize demand. Dry land area with low soil qualityespecially the limitation in physical, chemical, and biological characteristics were most dominated area of maize cultivation. Nevertheless, this soil is very potential for the development of maize production because the area of this soil was covered around 12,749,000 ha
(Askari, 2010). In efforts to increase maize production can be achieved by planting management, increasing fertilization and improved varieties, along with management of the physical and biological environment and the implementation of appropriate cultivation technology. In practices, maize cultivation was highly dependent to chemical fertilizer, pesticide and organic material nearly absent. This practice had been effect to decreasing of soil quality and high production cost. The adoption of better management practices (BMPs) can improve soil organic carbon (SOC) content, enhance soil quality, restore degraded ecosystems, increase biomass production, improve crop yield, and encourage investment in soil resources for soil restoration (Lal et al., 1998). 
Agriculture by product as organic material is often found in agricultural production area which was in many cases it become waste. The other organic material source comes from liquid (sludged) waste of biogas product. Both sources are potential material in producing bioameliorant. These materials can be used to produce liquid bio-ameliorant through anaerobic fermentation process (Setiawan, 2010). Combining of organic bioameliorant with chemical fertilizer could be alternate practice in optimizing maize production and maintain soil productivity. Benítez-Noyola (2013) demonstrated that maize plants fertilized with 90 and $180 \mathrm{Kg} \mathrm{N}^{-1}$ and inoculated with Paenibacillus polymyxa extracted from 20 to $28 \%$ more nitrogen and produced more grain than plants that were only chemically fertilized. The possibility of maintaining grain maize yields by replacing $87 \mathrm{Kg}$ urea $\mathrm{ha}^{-1}(50 \%)$ of the complete $\mathrm{N}$ fertilizer dose $\left(175 \mathrm{Kg} \mathrm{ha}^{-1}\right)$ with $300 \mathrm{Kg} \mathrm{ha}^{-1}$ of anorganic compost elaborated with fruit and vegetable wastes and enriched with $147 \mathrm{~g} \mathrm{~N}$ fertilizer $\mathrm{Kg}^{-1}$ compost (Naveed et al., 2008).

Based on this description is necessary to study the effect of interactions of liquid bio-ameliorant, reduction nitrogen fertilizer and planting space on soil quality and maize production. This study aimed to obtain maize cultivation technology in order to improve soil quality and increase production of maize through the combination application of liquid bio-ameliorant, reduction of nitrogen chemical fertilizer and crop management. Better knowledge and considerable information on maize cultivation management practices under integrating models are needed to generate effective strategies for achieving improvement soil quality and sustainable agriculture.

\section{Materials and methods}

Field experiment was carried out in Teaching Farm, Faculty of Agriculture, Hasanuddin University. The experiment was set up in a factorial experimental design replicated three times in $2 \times 2 \mathrm{~m}$ field plots. Treatment were arranged in three factors as: (1) planting space with two type spaces $\left(\mathrm{P}_{1}=75 \times 25 \mathrm{~cm}\right.$ and $\left.\mathrm{P}_{2}=50 \times 20 \mathrm{~cm}\right)$; (2) liquid bio-ameliorant (LBA) with three concentrations $\left(\mathrm{B}_{0}=0 \mathrm{ml} / \mathrm{l} ; \mathrm{B}_{1}=100 \mathrm{ml} / \mathrm{l} ;\right.$ and $\left.\mathrm{B}_{2}=300 \mathrm{ml} / \mathrm{l}\right)$; and (3) urea fertilizer with three levels $\left(\mathrm{N}_{0}=0 \mathrm{~kg} / \mathrm{ha} ; \mathrm{N}_{1}=300 \mathrm{~kg} / \mathrm{ha}\right.$; and $\mathrm{N}_{2}=240 \mathrm{~kg} / \mathrm{ha}$ ). Preparation of liquid bio-ameliorant was done by mixing all materials organic containing sludge of biogas, lake organic material sediment, plant by-product. This mixing organic material was collected and extracted into biodigester in $100 \mathrm{~L}$ capacity.
Developing biological activity of this material was using molasses, coconut water, and local microorganisms as bioactivator which were isolated from compost product. This process is carried out in three (3) biodigester with different composition formulation of in each biodigester. Liquid bio-ameliorant was ready for use after approximately four (4) weeks incubation. Liquid bioameliorant, soil and plant analysis was conducted at the Laboratory of Soil Chemistry and Fertility, Department of Soil Science, Faculty of Agriculture, Hasanuddin University, Makassar.

Liquid bio-ameliorant was starting applied two weeks after planting and it continued within every two weeks intervals during vegetative growth period. Nitrogen fertilizer treatment was applied in split three times: $40 \%$ in 7 Days After Planting (DAP), 30\% in 30 DAP, and $30 \% 50$ DAP. Furthermore, all plots were supplemented additionally with $150 \mathrm{~kg} / \mathrm{ha}$ super phosphate (SP36) and $100 \mathrm{~kg} / \mathrm{ha}$ potassium chloride $(\mathrm{KCl})$. Basic soil analysis was conducted which included: soil $\mathrm{pH}$ was measured in a 1:2.5 soil:solution ratio (in both water and $1 \mathrm{M} \mathrm{KCl}$ ) using a glass electrode. Exchangeable cations were extracted with $1 \mathrm{M}$ ammonium acetate (1:50 soil extractant ratio for $2 \mathrm{~h}$ ) and the filtered extract was analysed for $\mathrm{Ca}, \mathrm{Mg}, \mathrm{K}$ and $\mathrm{Na}$ by atomic absorption spectrophotometry. Total $\mathrm{N}$ by Kjeldahl digestion with colorimetric determination of liberated $\mathrm{NH}_{4}{ }^{+}$(Foster, $1995)$ and organic $\mathrm{C}$ by the Walkley and Black dichromate oxidation procedure (Blakemore et al., 1972). Samples were digested in nitric and perchloric acids and the $\mathrm{P}$ content of digests was measured by the molybdenum blue method (John, 1970). Statistically significant differences between the treatments of the experiment were analyzed using ANOVA and the effect of different treatment was evaluated using Duncan's multiple range test. All statistical analysis was performed using MStat-C computer package.

\section{Results and discussion}

\section{Change in soil quality}

Maize cultivation was highly depends on the soil fertility environmental conditions. In the soil with low nutrient content, especially nitrogen could be reduced maize production significantly. The application of inorganic fertilizer for long term tend to decreased soil quality which were direct affect to environment and plant production. The effect of liquid bio-ameliorant (LBA) had significant in change chemical and biological properties. As shown in Table 1 (change of soil chemical 
properties), and Table 2 (change of soil microbes density), it is clear result that liquid bio-ameliorant could be applied to reduce utilization of chemical fertilizer in improving soil quality.

Table 1. Change of oil chemical properties.

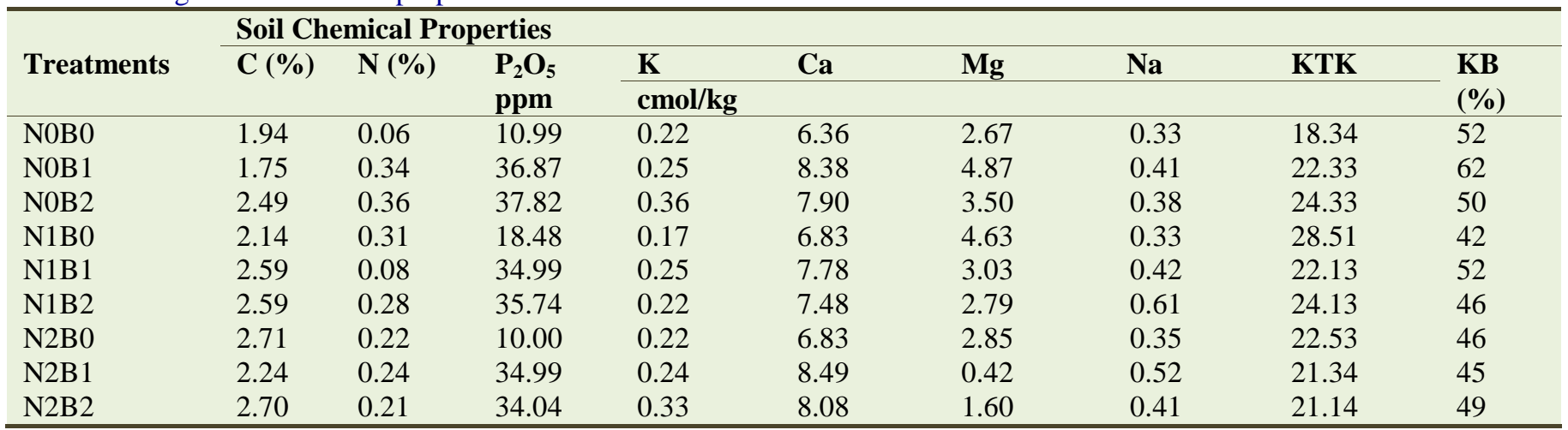

Soil chemical properties generally was higher in the liquid bio-ameliorant incorporation than in the anorganic fertilizer treatments. The result indicate that application $300 \mathrm{ml} / \mathrm{l}$ liquid bio-ameliorant in single treatment or combine with urea fertilizer produceda high value in all soil chemical parameters. The effect of liquid bio-ameliorant in reducing an-organic fertilizer could be found also when it compared to single urea treatment. The density ofsoil microbeas indication in change of soil biologi properties was highestin combination treatment $100 \mathrm{ml} / \mathrm{l}$ of liquid bio-ameliorant and $240 \mathrm{~kg} / \mathrm{ha}$ of ureafertilizer. The incorporation of liquid bio-ameliorant leads to more dynamic microbe activities compared to control or urea fertilizer addition. The result shown that there is approximately $28 \%$ increasing of microbe density in the application ofliquid bio-ameliorant. Hence, improving soil quality could be promote with reduction of inorganic fertilizer utilization and it substitute by liquid bio-ameliorant.

Table 2. Change of soil microbes density in each treatment.

\begin{tabular}{llll}
\hline Treatments & Replication I (cfu/g soil) & Replication II (cfu/g soil) & Average (cfu/g soil) \\
\hline $\mathrm{P}_{1} \mathrm{~B}_{0} \mathrm{~N}_{0}$ & $1 \times 10^{-4}$ & $1 \times 10^{-4}$ & $1.0 \times 10^{-4}$ \\
$\mathrm{P}_{2} \mathrm{~B}_{1} \mathrm{~N}_{1}$ & $1 \times 10^{-4}$ & $3 \times 10^{-4}$ & $2.0 \times 10^{-4}$ \\
$\mathrm{P}_{1} \mathrm{~B}_{2} \mathrm{~N}_{0}$ & $2 \times 10^{-4}$ & $5 \times 10^{-4}$ & $3.5 \times 10^{-4}$ \\
$\mathrm{P}_{1} \mathrm{~B}_{1} \mathrm{~N}_{0}$ & $8 \times 10^{-4}$ & $5 \times 10^{-4}$ & $6.5 \times 10^{-4}$ \\
$\mathrm{P}_{2} \mathrm{~B}_{2} \mathrm{~N}_{1}$ & $4 \times 10^{-4}$ & $5 \times 10^{-4}$ & $4.5 \times 10^{-4}$ \\
$\mathrm{P}_{2} \mathrm{~B}_{2} \mathrm{~N}_{2}$ & $8 \times 10^{-4}$ & $6 \times 10^{-4}$ & $7.0 \times 10^{-4}$ \\
$\mathrm{P}_{1} \mathrm{~B}_{0} \mathrm{~N}_{1}$ & $2 \times 10^{-4}$ & $2 \times 10^{-4}$ & $2.0 \times 10^{-4}$ \\
$\mathrm{P}_{1} \mathrm{~B}_{1} \mathrm{~N}_{2}$ & $13 \times 10^{-4}$ & $18 \times 10^{-4}$ & $15.5 \times 10^{-4}$ \\
$\mathrm{P}_{2} \mathrm{~B}_{0} \mathrm{~N}_{1}$ & $2 \times 10^{-4}$ & $3 \times 10^{-4}$ & $2.5 \times 10^{-4}$ \\
$\mathrm{P}_{1} \mathrm{~B}_{0} \mathrm{~N}_{2}$ & $8 \times 10^{-4}$ & $12 \times 10^{-4}$ & $10.5 \times 10^{-4}$ \\
$\mathrm{P}_{2} \mathrm{~B}_{1} \mathrm{~N}_{0}$ & $10 \times 10^{-4}$ & $7 \times 10^{-4}$ & $8.5 \times 10^{-4}$ \\
$\mathrm{P}_{2} \mathrm{~B}_{0} \mathrm{~N}_{0}$ & $4 \times 10^{-4}$ & $2 \times 10^{-4}$ & $3.0 \times 10^{-4}$ \\
$\mathrm{P}_{1} \mathrm{~B}_{1} \mathrm{~N}_{1}$ & $2 \times 10^{-4}$ & $1 \times 10^{-4}$ & $2.5 \times 10^{-4}$ \\
$\mathrm{P}_{1} \mathrm{~B}_{2} \mathrm{~N}_{1}$ & $6 \times 10^{-4}$ & $1 \times 10^{-4}$ & $3.5 \times 10^{-4}$ \\
$\mathrm{P}_{2} \mathrm{~B}_{2} \mathrm{~N}_{0}$ & $2 \times 10^{-4}$ & $1 \times 10^{-4}$ & $1.5 \times 10^{-4}$ \\
$\mathrm{P}_{2} \mathrm{~B}_{0} \mathrm{~N}_{2}$ & $2 \times 10^{-4}$ & $4 \times 10^{-4}$ & $3.0 \times 10^{-4}$ \\
$\mathrm{P}_{1} \mathrm{~B}_{2} \mathrm{~N}_{2}$ & $2 \times 10^{-4}$ & $6 \times 10^{-4}$ & $4.0 \times 10^{-4}$ \\
$\mathrm{P}_{2} \mathrm{~B}_{1} \mathrm{~N}_{2}$ & $20 \times 10^{-4}$ & $21 \times 10^{-4}$ & $20.5 \times 10^{-4}$ \\
\hline
\end{tabular}

\section{Plant performance}

Total plant height was shown clear effect of liquid bioameliorant and nitrogen fertilizer to plant height in single or combination treatment, however planting space was same effect in both types application (Table 3). The highest result was performed in the treatment $100 \mathrm{ml} / \mathrm{l}$ LBA with $300 \mathrm{~kg} / \mathrm{ha}$ urea. However, statistically it had not significant in the treatment $300 \mathrm{ml} / \mathrm{l} \mathrm{LBA}$ with 240 $\mathrm{kg} / \mathrm{ha}$ urea. 
Table 3. Effect of liquid bio-ameliorant, nitrogen, and planting space on plant height $(\mathrm{cm})$.

\begin{tabular}{lll}
\hline Treatments & Average & Note* \\
\hline $\mathrm{P}_{1} \mathrm{~B}_{1} \mathrm{~N}_{1}$ & 198.07 & $\mathrm{a}$ \\
$\mathrm{P}_{2} \mathrm{~B}_{1} \mathrm{~N}_{1}$ & 185.60 & $\mathrm{a}$ \\
$\mathrm{P}_{2} \mathrm{~B}_{0} \mathrm{~N}_{1}$ & 184.64 & $\mathrm{a}$ \\
$\mathrm{P}_{1} \mathrm{~B}_{2} \mathrm{~N}_{2}$ & 183.57 & $\mathrm{a}$ \\
$\mathrm{P}_{2} \mathrm{~B}_{2} \mathrm{~N}_{2}$ & 183.55 & $\mathrm{a}$ \\
$\mathrm{P}_{2} \mathrm{~B}_{1} \mathrm{~N}_{2}$ & 183.00 & $\mathrm{a}$ \\
$\mathrm{P}_{2} \mathrm{~B}_{2} \mathrm{~N}_{1}$ & 178.86 & $\mathrm{ab}$ \\
$\mathrm{P}_{2} \mathrm{~B}_{0} \mathrm{~N}_{2}$ & 177.90 & $\mathrm{~b}$ \\
$\mathrm{P}_{1} \mathrm{~B}_{1} \mathrm{~N}_{2}$ & 177.33 & $\mathrm{~b}$ \\
$\mathrm{P}_{1} \mathrm{~B}_{0} \mathrm{~N}_{1}$ & 176.03 & $\mathrm{~b}$ \\
$\mathrm{P}_{1} \mathrm{~B}_{0} \mathrm{~N}_{2}$ & 171.43 & $\mathrm{~b}$ \\
$\mathrm{P}_{1} \mathrm{~B}_{2} \mathrm{~N}_{1}$ & 167.90 & $\mathrm{~b}$ \\
$\mathrm{P}_{2} \mathrm{~B}_{1} \mathrm{~N}_{0}$ & 157.65 & $\mathrm{bc}$ \\
$\mathrm{P}_{2} \mathrm{~B}_{0} \mathrm{~N}_{0}$ & 153.19 & $\mathrm{c}$ \\
$\mathrm{P}_{2} \mathrm{~B}_{2} \mathrm{~N}_{0}$ & 150.55 & $\mathrm{c}$ \\
$\mathrm{P}_{1} \mathrm{~B}_{2} \mathrm{~N}_{0}$ & 143.50 & $\mathrm{c}$ \\
$\mathrm{P}_{1} \mathrm{~B}_{1} \mathrm{~N}_{0}$ & 137.77 & $\mathrm{c}$ \\
$\mathrm{P}_{1} \mathrm{~B}_{0} \mathrm{~N}_{0}$ & 134.37 & $\mathrm{c}$ \\
\hline
\end{tabular}

*The same letter in the note colum was not significantly different at $1 \%$ Duncan's test.

Table 4. The differences of plant biomass weight $(\mathrm{g})$ in liquid bio-ameliorant, nitrogen fertilizer and planting space treatments.

\begin{tabular}{lll}
\hline Treatments & Average & Note* \\
\hline $\mathrm{P}_{1} \mathrm{~B}_{1} \mathrm{~N}_{1}$ & 124.00 & $\mathrm{a}$ \\
$\mathrm{P}_{1} \mathrm{~B}_{0} \mathrm{~N}_{2}$ & 119.27 & $\mathrm{a}$ \\
$\mathrm{P}_{1} \mathrm{~B}_{1} \mathrm{~N}_{2}$ & 110.83 & $\mathrm{a}$ \\
$\mathrm{P}_{2} \mathrm{~B}_{2} \mathrm{~N}_{2}$ & 109.43 & $\mathrm{a}$ \\
$\mathrm{P}_{1} \mathrm{~B}_{2} \mathrm{~N}_{1}$ & 98.77 & $\mathrm{a}$ \\
$\mathrm{P}_{2} \mathrm{~B}_{2} \mathrm{~N}_{1}$ & 96.97 & $\mathrm{a}$ \\
$\mathrm{P}_{1} \mathrm{~B}_{0} \mathrm{~N}_{1}$ & 96.37 & $\mathrm{a}$ \\
$\mathrm{P}_{2} \mathrm{~B}_{0} \mathrm{~N}_{1}$ & 85.60 & $\mathrm{ab}$ \\
$\mathrm{P}_{1} \mathrm{~B}_{2} \mathrm{~N}_{0}$ & 82.37 & $\mathrm{~b}$ \\
$\mathrm{P}_{1} \mathrm{~B}_{2} \mathrm{~N}_{2}$ & 80.00 & $\mathrm{~b}$ \\
$\mathrm{P}_{2} \mathrm{~B}_{1} \mathrm{~N}_{2}$ & 75.47 & $\mathrm{~b}$ \\
$\mathrm{P}_{2} \mathrm{~B}_{1} \mathrm{~N}_{1}$ & 67.27 & $\mathrm{~b}$ \\
$\mathrm{P}_{2} \mathrm{~B}_{1} \mathrm{~N}_{0}$ & 61.53 & $\mathrm{~b}$ \\
$\mathrm{P}_{2} \mathrm{~B}_{2} \mathrm{~N}_{0}$ & 57.57 & $\mathrm{~b}$ \\
$\mathrm{P}_{2} \mathrm{~B}_{0} \mathrm{~N}_{0}$ & 56.83 & $\mathrm{~b}$ \\
$\mathrm{P}_{1} \mathrm{~B}_{1} \mathrm{~N}_{0}$ & 54.00 & $\mathrm{~b}$ \\
$\mathrm{P}_{1} \mathrm{~B}_{0} \mathrm{~N}_{0}$ & 53.57 & $\mathrm{bc}$ \\
$\mathrm{P}_{2} \mathrm{~B}_{0} \mathrm{~N}_{2}$ & 51.50 & $\mathrm{c}$ \\
\hline
\end{tabular}

*The same letter in note column was not significantly different at $1 \%$ Duncan's test.

The effect of planting space generally had shown better performance in the treatment $50 \times 20 \mathrm{~cm}$ compared to planting space $75 \times 25 \mathrm{~cm}$. In overall treatment, plant height was significantly lower in the single treatment of
LBA or urea fertilizer. The difference in plant height was informed that LBA could be applied as complement of nitrogen fertilizer. The result also suggesting that higher concentration treatment of LBA and reducing nitrogen fertilizer had not significant effect than lower concentration LBA and higher nitrogen fertilizer.

Plant biomass was obtained after plant harvest and it dry in $70^{\circ} \mathrm{C}$ for $48 \mathrm{hrs}$ following to dry weight determination. Combination treatments of $100 \mathrm{ml} / 1 \mathrm{LBA}, 300 \mathrm{~kg} / \mathrm{ha}$ urea, and $75 \times 25 \mathrm{~cm}$ planting space were the highest dry weight (Table 4). Although, it had no significant effect statistically in different planting space treatment but $75 \times 25 \mathrm{~cm}$ planting space had higher dry weight than other treatment. In general result was found that treatment without LBA or nitrogen fertilizer lower than combining of both treatments. An interesting result also found that higher concentration of LBA $(300 \mathrm{ml} / \mathrm{l})$ and lower nitrogen fertilizer $(240 \mathrm{~kg} / \mathrm{ha})$ could be maintain high biomass production.

\section{Plant nutrient uptake}

Plant nutrient uptake could be an important indicator in soil-plant relationship. In the soil with high nutrient availability had easy to be trace in the nutrient plant content. The amount of nutrient uptake (N and $\mathrm{P})$ in all treatments were shown in Table 5. Nitrogen and phosphorous uptake by plant was clearly affected by different treatments. The high content in nutrient uptake was almost dominated by combination treatments of LBA and nitrogen fertilizer. Planting space effect on nutrient uptake was generally higher in $75 \times 25 \mathrm{~cm}$ treatment than $50 \times 20 \mathrm{~cm}$ planting space. The result also shown that plant can uptake nitrogen and phosphorous relatively higher amountin LBA treatment without nitrogen fertilizer application.

\section{Plant Production}

Plant production is illustrates the working of interactions of various factors which is determine allproduction process including soil, fertilizers, and the production environment. Total production in this experiment was shown in Table 6 . The highest production was shown in combination treatments between $300 \mathrm{ml} / \mathrm{l} \mathrm{LBA}$ and 240 $\mathrm{kg} / \mathrm{ha}$ nitrogen fertilizer with $50 \times 20 \mathrm{~cm}$ planting space. The result was found also that LBA improving environmental production as reducing nitrogen fertilizer. The result could be used to confirmed the usefulness of liquid bio-ameliorant as material in improving maize production especially in sub-optimal soil. 
Table 6. Total production in different combination treatments.

\begin{tabular}{lll}
\hline Treatments & $\begin{array}{l}\text { Production }(\mathbf{k g}) \\
\text { (in plots } \mathbf{2 \times 2} \mathbf{M})\end{array}$ & $\begin{array}{l}\text { Production } \\
\text { (ton/ha) }\end{array}$ \\
\hline $\mathrm{P}_{1} \mathrm{~B}_{1} \mathrm{~N}_{1}$ & 5.40 & 5.32 \\
$\mathrm{P}_{2} \mathrm{~B}_{2} \mathrm{~N}_{2}$ & 7.92 & 9.00 \\
$\mathrm{P}_{2} \mathrm{~B}_{0} \mathrm{~N}_{1}$ & 3.24 & 3.12 \\
$\mathrm{P}_{1} \mathrm{~B}_{0} \mathrm{~N}_{0}$ & 2.64 & 3.00 \\
\hline
\end{tabular}

\section{Conclusion}

Sustainability of maize production was affected by environmental management and soil fertility factors. Plant performance had high results under combination treatments between low liquid bioameliorant concentration and high nitrogen fertilizer application. Similarly, nutrient plant uptake was shown result compared to the other treatments. The difference effect was found in total production which was shown the highest production in combination treatments of high LBA concentration and low nitrogen fertilizer. This result confirmed and it concluded that liquid bioameliorant could be used as fertilizer complement and reducing inorganic fertilizer. For the future, liquid bioameliorant has potential bio material in improving maize production sustainability.

\section{Conflict of interest statement}

Authors declare that they have no conflict of interest.

\section{Acknowledgement}

We greatly acknowledge all students involved this experiment for their assistance in the field and Department of Soil Science, Faculty of Agriculture, Hasanuddin University for laboratory facilities in soil and plant samples analysis. This research would have been impossible without financial support through university exellent research program of Directorate General of Higher Education, Ministry of Research, Technology, and Higher Education, Indonesia.

\section{References}

Askari, 2010. Sifat Kimia Alfisol Pertanian Organikdan Anorganik. J. Ilmu Tanah. 10, 63-69.

Benítez-Noyola, M., 2013. Inoculación con Paenibacillus polymyxa yfertilización nitrogenada en maízbajo condiciones de temporal. M. Sc. Thesis. Colegio de Postgraduados. Montecillo, Texcoco, Edo de México, México.

Blakemore, L.C., Searle, P.L., Daly, B. K., 1972. Methods for Chemical Analysis of Soils. New Zealand Soil Bureau Report, 10A. Government Printer, Wellington.

BPS, 2014. Luas Panendan Produksi Jagung Nasional. Badan Pusat Statistik. Jakarta.

Foster, J. C., 1995. Soil nitrogen. In: Methods in Applied Soil Microbiology and Biochemistry (Eds.: Alef, K., Nannipieri, P). Academic Press, London. pp.79-81.

John, M.K., 1970. Colorimetric determination of phosphorus in soil and plant materials with ascorbic acid. Soil Sci. 109, 214-220.

Lal, R., Kumble, J.M., Follett, R.F., Cole, C.V., 1998. The Potential of U.S. Cropland to Sequester Carbon and Mitigate the Greenhouse Effect. Ann Arbor Press, Chelsea, MI.

Naveed, M., Khalid, M., Jones, D. L., Ahmad, R., Zahir, Z. A., 2008. Relative efficacy of Pseudomonas spp., containing ACC-deaminase for improving growth and yield of maize (Zea mays L.) in the presence of organic fertilizer. Pak. J. Bot. 40, 1243-1251.

Setiawan, 2010. Pengolahan Limbah Organikdengan EM sebagai Bahan Baku Pembuatan Kompos. Fakultas Kesehatan Masyrakat UNDIP, Semarang.

\section{How to cite this article:}

Rasyid, B., Syafiuddin, M., Ansar, M., 2016. Functioning of liquid bio-ameliorant in reduction of inorganic fertilizer to improve soil quality and maize productivity. Int. J. Curr. Res. Biosci. Plant Biol. 3(5), 6-10. doi: http://dx.doi.org/10.20546/ijcrbp.2016.305.002 